\title{
Analysis Proximate, HCN , Antioxidant Compounds And Antioxidant Activities Of Potential Extract As Antiatherosclerosis
}

\section{Edy Soesanto}

University of Muhammadiyah Semarang

\section{Article Info}

\section{Article History:}

Accepted Oct 23rd 2018

\section{Key words:}

analysis of chemical compounds; antioxide activity; bamboo shoots; antiatherosclerosis

\section{PENDAHULUAN}

Kasus Penyakit Jantung Koroner di

Indonesia semakin sering ditemukan dan
Bamboo shoots are plants that are very easy to find in Indonesia and can grow anywhere, economically bamboo shoots are very cheap and have been used by people in the world as foodstuffs since time immemorial. Aside from being a bamboo shoot food, it also has functions related to hypocholesterolemia, so it can be used as an alternative nonpharmacological treatment or as a traditional medicine derived from medicinal plants (Complementary Therapy). This study aims to determine the levels of protein, fat, water, ash, carbohydrates, HCN, phenols, flavonoids, vitamin E from bamboo shoots and their antioxidant activity. Bamboo shoots used include: yellow bamboo shoots, wulung, green, apus and betung. Bamboo shoots are thinly sliced and dried in an oven of $800 \mathrm{C}$ for 24 hours and smoothed to get bamboo shoot powder and then extracted using $70 \%$ ethanol which will be analyzed for chemical compounds using the SNI 01-2891-1992 method for proximate test, HCN test using AOAC, while testing phenol, flavonoids, and vitamin E compounds using a spectrophotometer, testing antioxidant activity using DPPH method. The results of the proximate test analysis of 5 bamboo shoot extract samples showed that yellow bamboo shoots contained at most $0.632 \%$ fat, $4.474 \%$ water, $0.878 \mathrm{gr}$ ash, $29.78 \%$ carbohydrates and $4.12 \mathrm{gr}$ crude fiber. The highest protein content test of $0.41 \%$ was found in Apus bamboo shoots extract and the highest HCN content was also in Apus bamboo shoot extract $3.98 \mathrm{mg} / 100 \mathrm{gr}$. The highest content of Vitamin E is found in Apus bamboo shoots extract which is $0.3284 \%$, the highest total flavonoid content is found in green bamboo shoots extract that is equal to $0.02778 \%$, the most phenolic content in bamboo shoots extract is apus bamboo shoots extract of $4.4352 \%$ and the test results Apus bamboo antioxidant activity is more active as an antioxidant than other bamboo shoots which is $171.15 \mu \mathrm{g} / \mathrm{mL}$ with IC 50 value. This shows that Apus bamboo shoots extract is relatively safe for consumption and has good antioxidant potential and can be used as traditional medicine which comes from medicinal plants (Complementary Therapy).

Corresponding author:

Edy Soesanto

soesantoedisoes@gmail.com

Media Keperawatan Indonesia, Vol 1 No 3, October 2018

e-ISSN: 2615-1669

DOI:10.26714/mki.1.3.2018.32-45 
1.000 penduduk Indonesia menderita Penyakit Jantung Koroner, 5,1 persen dari semua kematian disebabkan oleh penyakit jantung iskemia dan 4,6 persen disebabkan penyakit jantung serta menjadi penyebab kematian kedua tertinggi di Indonesia dengan persentase 9,7 persen.

Sebagian besar Penyakit Jantung Koroner terjadi karena penyumbatan pada pembuluh darah yang diakibatkan adanya proses ateroklerosis (Ganong,1983). Kolesterol yang berlebihan dalam pembuluh darah akan mengalami oksidasi dan mengalami interaksi dengan sel makrofag dan substansi biologik lainnya akan membentuk sel busa (foam cell) yang akan menumpuk dalam dinding pembuluh darah, kemudian menyusup kedinding arteri dan membentuk suatu kerak / plak dan apabila pecah dapat menyumbat aliran darah pada pembuluh arteri (arteria koroner) yang menyebabkan kematian sel otot jantung ( miokard infarct).

Pola makan yang tidak sehat adalah satu faktor yang dapat mengakibatkan terjadinya aterosklerosis, konsumsi makanan tinggi lemak dan karbohidrat, garam sodium yang tinggi, rendah serat dan minuman beralkohol (Soesanto E, 2010). Penurunan kadar kolesterol sering dilakukan oleh masyarakat dengan mengkonsumsi obat hipolipidemia, tetapi harga obat-obatan hipolipidemia sangat mahal. Pemakaian obat sintesis sering menimbulkan efek samping seperti nyeri lambung, nyeri abdomen, urtikaria, disuria, penurunan berat badan, ikhtiosis, insomnia, depresi, dan dysgeusia (Kamaluddin, 1992) dan adanya kontraindikasi terhadap penyakit tertentu yang juga diderita oleh penderita aterosklerosis.

Pencarian obat hipolipidemia terutama yang berasal dari alam dan tumbuhan terus dilakukan. Obat-obatan dari tumbuhan selain mudah didapat harganya murah , juga memiliki efek samping yang kecil sehingga relatif aman jika dibandingkan obat-obatan sintesis. Salah satu tanaman yang bersifat hipolipidemia yang dapat digunakan sebagai dasar bahan obat-obatan adalah rebung (shoot bamboo).

Rebung bambu dipercaya untuk menurunkan kadar kolesterol darah, obat sakit kuning/lever (sirosis hati), obat bengkak, batuk berdahak dan demam. Serat rebung yang mengandung lignin (insoluble fiber), pectin dan glucans (soluble fiber) mempunyai efek mengikat zat-zat organik seperti asam empedu dan kolesterol sehingga dalam saluran pencernaan mampu menurunkan jumlah asam lemak (Olwin, 2005). Serat mampu mengikat empedu, menyebabkan asam empedu keluar dari siklus enterohepatic dan tidak diabsorbsi tetapi langsung terbuang bersama feses, sehingga hal ini menyebabkan hepar 
menggunakan kolesterol untuk meningkatkan asam empedu. Diduga pula bahwa dengan keberadaan serat akan menghambat emulsifikasi lemak dan kolesterol oleh garam empedu, sehingga kolesterol akan terikat oleh serat yang kemudian akan dikeluarkan melalui ekskreta (Hernawati, 2005 ).

Beberapa studi atau penelitian membuktikan bahwa rebung dapat menurunkan tekanan darah karena kandungan kaliumnya yang tinggi dan pithopenolnya merupakan antioksidan (Parekh.J and Chanda.S,2007). Menurunkan glukosa darah, profil lipid, fungsi hepatik dan gejala sembelit (Park.E.J, John.D.Y, 2009; Jiao.J,2008; Jiao.J, 2008). Kandungan bioaktif lignophenol mempunyai peran sebagai anti oksidan dan menekan apoptosis pada sel neuroblastoma SH-SY5Y (Akao Y ,2004; Hu CH,2000). Daun bambu yang kaya dengan polyphenol , C-glucosides and p-coumaric acid merupakan senyawa antioksidan (Lu.B,2006; Zhang.Y,2007). Kandungan Tricin (5,7,4'-trihydroxy-3',5'dimethoxyflavone) dalam daun bambu merupakan senyawa antioksidan terhadap pertumbuhan sel kanker (Jiao.J,200). Rebung dapat juga digunakan sebagai antiinflamasi (Rana, 2008).

Berdasarkan uraian diatas bahwa rebung merupakan tanaman yang sangat mudah dijumpai di Indonesia dan dapat tumbuh dimana saja, secara ekonomis rebung sangat murah serta telah digunakan oleh masyarakat di dunia sebagai bahan pangan sejak jaman dahulu. Selain sebagai bahan makanan rebung juga memiliki fungsi yang terkait dengan sifat hipokolesterolemi, sehingga dapat dijadikan sebagai salah satu alternatif pengobatan non farmakologi atau sebagai obat tradisional yang berasal dari tanaman obat (Complementary Therapy), maka dirasa perlu untuk dilakukan penelitian lebih lanjut. Penelitian ini bertujuan untuk mengetahui kandungan senyawa senyawa kimia dan aktivitas antioksidan pada beberapa varietas rebung bambu.

\section{METODE}

\section{Bahan Penelitian}

Bahan yang digunakan untuk diteliti adalah rebung segar yang biasa digunakan sebahan baku pangan dan obat yaitu rebung bambu wulung, kuning, apus, hijau dan betung. Diperoleh dari tanaman yang tumbuh dikebun bambu masyarakat di desa Banyumeneng, kecamatan Mranggen, kabupaten Demak, pada bulan mei tahun 2018. Bahan kimia yang digunakan dalam pengujian kadar protein terdiri atas $\mathrm{H}_{2} \mathrm{SO}_{4}$, Silenium, $\mathrm{NaOH} 40$ \%, Indikator MR, Asam Borat dan $\mathrm{HCl}$, pengujian kadar lemak terdiri atas reagen benzen dan eter, pengujian kadar $\mathrm{HCN}$ terdiri atas $\mathrm{NaOH}$, 
$\mathrm{NH}_{4} \mathrm{OH}, \mathrm{AgNO}_{3}$, dan $\mathrm{HNO}_{3}$, pengujian serat kasar menggunakan zat anti buih, $\mathrm{H}_{2} \mathrm{SO}_{4}$, $\mathrm{NaOH}, \mathrm{K}_{2} \mathrm{SO}_{4} 10 \%$ dan alkohol. Pengujian kadar plavonoid menggunakan larutan standar flavonoid rutin, metanol, pengujian kadar phenol menggunakan aquades, reagen Folin-Ciocalteu, sodium karbonat jenuh, pengujian kadar vitamin $\mathrm{E}$ menggunakan PE. gas nitrogen, toluene, larutan 2,2 bipiridin dalam etanol dan ferri klorida dalam etanol 0,02\% serta untuk pengujian aktivitas antioksidan menggunakan Reagen Lar. DPPH dan Methanol (semuanya dengan grade pa dari Merck).

Alat yang digunakan untuk analisis proksimat, yaitu perangkat destruksi, analisis HCN menggunakan perangkat destilasi, analisis serat kasar menggunakan soxhlet serta untuk pengujian senyawa antioksidan dan aktivitas antioksidan menggunakan spektrofotometer UV-VIS.

\section{Pembuatan ekstrak rebung.}

Rebung dilepas dari kelopaknya dan diiris tipis tipis, direndam dalam air selama 24 jam (tiap 12 jam airnya diganti) kemudian dikeringkan dengan oven pada suhu $80{ }^{\circ} \mathrm{C}$, digiling dengan mesin sehingga diperoleh serbuk rebung bambu dan dilakukan proses ekstraksi dengan menggunakan etanol 90 $\%$.

\section{Analisis Proksimat}

Analisis proksimat dilakukan berdasarkan metode SNI 01-2891-1992 yang dimodifikasi dan dilakukan 2 kali ulangan.

\section{Analisis Kadar Protein}

Bahan ditimbang 0.05 gr, dimasukkan dalam labu destruksi dan ditambahkan $\mathrm{K}_{2} \mathrm{SO} 40.333$ gr, $\mathrm{ZnSO}_{4} 0.133$ gr, $\mathrm{HgO} 0.33$ gr, $1 \mathrm{ml} \mathrm{H}_{2} \mathrm{SO}_{4}$ pekat lalu dipanaskan dalam ruang asam sampai berwarna jernih, kemudian didinginkan.

Hasil desturksi ditambah aquades sedikit demi sedikit sampai $\pm 1 / 2$ dari labu destilat, kemudian ditambahkan indikator PP dan $\mathrm{NaOH}$ sebanyak $5 \mathrm{ml}$. Indikator BCG dimasukkan kedalam wadah yang telah berisi hasil sulingan dan asam borat (warna hijau). Kadar protein ditetapkan dengan perhitungan sebagai berikut:

$\%$ Nitrogen $=\frac{(\text { blangko }- \text { sampel }) \times N N a O H \times 0,014}{\text { berat contoh }(g r)}$

\section{Analisis kadar lemak}

Labu Soxhlet dikeringkan dalam oven, didinginkan dalam desikator, dan ditimbang. 5 gram sampel (halus) ditaruh dalam kertas saring, ditutup dengan kapas wool (bebas lemak), kemudian dimasukkan dalam Soxhlet, kemudian dipasang alat kondensor dan labu lemak. 
Labu lemak diisi pelarut dietil eter, direfluks selama 5 jam sampai pelarut berwarna jernih kemudian didistilasi. Selanjutnya hasil ekstraksi dipanaskan pada suhu $105^{\circ} \mathrm{C}$ dan setelah kering dilanjutkan pendinginan (desikator), labu ditimbang beserta lemaknya. Berat lemak dihitung dengan rumus sebagai berikut:

$$
\% \text { Lemak }=\frac{\text { berat lemak }(g)}{\text { berat sampel }} \times 100
$$

\section{Analisis kadar air}

Krus porselin dimasukkan kedalam oven $105-110^{\circ} \mathrm{C}$ selama 15 menit dan didinginkan dalam desikator selama 20 menit kemudian ditimbang sampai didapat berat yang konstan. Ditimbang secara kuantitatif 2.5 gr tepung formula dimasukkan ke dalam kurs porselen, kemudian dimasukkan dalam oven dengan suhu $105-100^{\circ} \mathrm{C}$ selama 5 jam sampai didapat berat yang konstan. Kadar air dihitung :

$$
\text { kadar air }=\frac{\text { bobot awal }- \text { bobot kering }}{\text { bobot kering }} \times 100 \%
$$

\section{Analisis kadar abu}

Timbang dengan seksama lebih kurang 2 gr - 10 gr contoh dalam krus porselin yang kering dan telah diketahui beratnya sebelumnya, kemudian pijarkan dalam muffle sampai diperoleh abu dan ditimbang.

\section{Analisis kadar karbohidrat}

Perhitungan kadar karbohidrat suatu bahan pangan dapat dihitung secara perbedaan antara jumlah kandungan air, protein, lemak dan abu dengan rumus : 100\% - (protein + lemak + abu + air).

\section{Analisa Kadar Serat Kasar}

\begin{tabular}{lrr} 
Penghitungan & kadar serat kasar \\
dilakukan dengan & cara sampel halus \\
sebanyak 2 gram & kemudian & diekstraksi \\
dengan metode & soxhletasi. & Sampel \\
dimasukkan ke dalam Erlenmeyer & $600 \mathrm{ml}$ \\
\multicolumn{4}{l}{ yang sudah ditambah dengan zat anti buih }
\end{tabular}
dan $200 \mathrm{ml}$ larutan $\mathrm{H}_{2} \mathrm{SO}_{4}$ mendidih, kemudian ditutup dengan pendingin balik. Selama 30 menit dipanaskan sampai mendidih dengan dan digoyang-goyang. Suspensi yang dihasilkan disaring dengan kertas saring dan residu yang tertinggal dicuci dengan air mendidih sampai tidak bersifat asam (lakmus tes). Sisanya dicuci lagi dengan $200 \mathrm{ml}$ larutan $\mathrm{NaOH}$ mendidih dan dipanaskan selama 30 menit dengan pendingin balik sambil digoyang goyangkan. Disaring kembali dan dicuci dengan larutan $\mathrm{K}_{2} \mathrm{SO}_{4} 10 \%$. Dicuci lagi dengan residu dengan air mendidih, kemudian dengan alkohol sekitar $15 \mathrm{ml}$. Kertas saring dikeringkan pada suhu $110^{\circ} \mathrm{C}$ sampai berat konstan (1-2 jam). Didinginkan dalam desikator dan ditimbang. 
Serat Kasar $=$ Berat residu yang diperoleh .

\section{Analisis Kadar Hidrosianida : HCN}

Maserasikan 50 g serbuk rebung dalam 50 $\mathrm{ml}$ air pada erlenmeyer $250 \mathrm{ml}$ dan tambahkan $10 \mathrm{ml}$ larutan asam tartrat $5 \%$. Kertas saring ukuran 1x7 cm dicelupkan dalam larutan asam pikrat jenuh, kemudian dikeringkan di udara, setelah kering dibasahi dengan larutan $\mathrm{Na}_{2} \mathrm{CO}_{3} 80 \%$ dan digantungkan pada leher erlenmeyer di atas, dan ditutup hingga kertas tak kontak dengan cairan dalam erlenmeyer. Kemudian panaskan dengan suhu $50{ }^{\circ} \mathrm{C}$ selama 15 menit, apabila warna oranye dari kertas piktat berubah menjadi warna merah berarti terdapat HCN secara kualitatif.

Timbang 20 gr rebung yang halus, tambahkan $100 \mathrm{ml}$ aquades dalam labu Kjeldahl, maserasikan (rendam) selama 2 jam. Tambahkan lagi $100 \mathrm{ml}$ aquades dan distilasi dengan uap (steam destillation). Distilat ditampung dalam erlenmeyer yang telah diisi dengan $20 \mathrm{ml} \mathrm{NaOH} \mathrm{2,5 \% .}$ Setelah distilat mencapai $150 \mathrm{ml}$, distilasi dihentikan. Distilat kemudian ditambah 8 $\mathrm{ml} \mathrm{NH}{ }_{4} \mathrm{OH}, 5 \mathrm{ml} \mathrm{Kl} \mathrm{5 \%} \mathrm{dan} \mathrm{dititrasi} \mathrm{dengan}$ larutan $\mathrm{AgNO}_{3} \quad 0.02 \mathrm{~N}$ sampai terjadi kekeruhan.

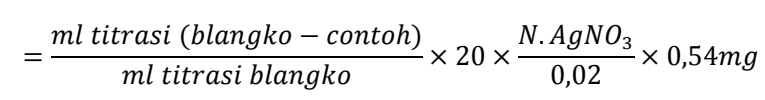

\section{Uji Total phenol}

Diambil bahan bahan sebanyak $1 \mathrm{~g}$ ditambahkan dengan aquades $70 \mathrm{ml}$ dalam labu ukur $100 \mathrm{ml}$. Ditambahkan reagen Folin-Ciocalteu sebanyak $5 \mathrm{ml}$. Setelah 1 menit dimasukkan sodium karbonat jenuh sebanyak $15 \mathrm{ml}$. Ditambahkan aquades sampai tepat $100 \mathrm{ml}$, kemudian dilakukan homogenisasi dengan shaker. Sampel didiamkan selama 2 jam. Sampel dibaca dengan menggunakan spektrofotometer pada panjang gelombang $760 \mathrm{~nm}$.

\section{Uji Plavonoid}

Pembuatan larutan standar, menggunakan larutan standar flavonoid rutin, optimasi panjang gelombang, menentukan absorbansi isolat murni senyawa flavonoid, dan kalibrasi hasil pengukuran Larutan standar yang dipakai yaitu senyawa flavonoid rutin dengan konsentrasi 0,10 , 20, 30, 40, dan 50 mg.L-1. Dari larutan standar induk 1000 mg.L-1 masing-masing dibuat $25 \mathrm{~mL}$ dalam pelarut methanol.

1000 g senyawa rutin, dimasukkan dalam gelas piala ukuran $100 \mathrm{~mL}$ dan dilarutkan dalam $50 \mathrm{~mL}$ etanol dan diaduk sampai homogen, kemudian dimasukkan dalam labu takar $1000 \mathrm{~mL}$ dan ditambahkan etanol sampai tanda dan dikocok hingga homogen. Larutan standar induk, diencerkan menjadi 100 mg.L-1 dengan 
dipipet sebanyak $10 \mathrm{~mL}$. Diencerkan dengan etanol dalam labu takar $100 \mathrm{~mL}$ sampai tanda batas. Larutan standar 10, 20, 30, 40, dan 50 mg.L-1 masing-masing diencerkan dengan pelarut etanol dalam labu takar $25 \mathrm{~mL}$ sampai tanda dan dikocok hingga homogen. Etanol murni digunakan sebagai blanko.

Penentuan absorbansi larutan standar dan sampel pada panjang gelombang maksimum dengan menggunakan spektrofotometer UV-Vis dengan persamaan regresi linear. Hasil yang diperoleh diperhitungkan dengan faktor pengenceran sehingga diperoleh konsentrasi flavonoid yang terdapat dalam ekstrak etanol rebung.

\section{Uji Vitamin E}

Ditimbang sampel yang telah dihaluskan kemudian diekstrasi dengan PE. Campuran divortek sampai seluruh minyak terekstrasi.Hasil ekstrasi dipindahkan dalam labu takar $10 \mathrm{ml}$ kemudian diuapkan dengan gas nitrogen untuk memperoleh minyak.Selanjutnya ditambah $5 \mathrm{ml}$ toluene; 3,5 ml larutan 2,2 bipiridin dalam etanol 0,07\% (b/v) dan 0,5 ml ferri klorida dalam etanol 0,02\% (b/v) dan akhirnya ditambah etanol sampai tanda. Sampel divoertek selama beberapa menit sehingga warnanya dapat terbentuk secara sempurna dan dibiarkan selama 1 menit, selanjutnya ditera dengan spektrootometer pada.

\section{Uji Aktivitas Antioksidan}

Penentuan aktivitas penangkal radikal bebas dengan metode Gaulejac et al. (2011) yang sedikit dimodifikasi. Ekstrak methanol dan air (kering dan basah) diambil sebanyak 0,5 $\mathrm{mL}$ ditambahkan larutan DPPH sebanyak $2 \mathrm{~mL}$ dan selama 2 menit divortex. Efisiensi radikal bebas dilihat dari perubahan warna larutan ungu ke kuning. Absorbansi diukur pada panjang gelombang $517 \mathrm{~nm}$ dengan menggunakan spektrofotometer UV-VIS pada 5 menit terakhir menjelang 30 menit inkubasi. Aktivitas antioksidan dihitung sebagai presentase berkurangnya warna DPPH dengan menggunakan persamaan : ( $\mathrm{n} x$ $100 \%$ ). Dari harga \% antioksidan yang diperoleh, dibuat kurva standar antara persentase $(\%)$ antioksidan terhadap konsentrasi larutan uji. Dari persamaan regresi linier tersebut dapat ditentukan nilai $\mathrm{IC}_{50}$, yaitu konsentrasi inhibisi larutan rebung yang mampu menangkal $50 \%$ radikal bebas.

\section{HASIL}

Proses pembuatan ekstrak rebung diperoleh dari rebung bambu segar diiris tipis kemudian dikeringkan dalam oven bersuhu $80 \quad 0 \quad$ C selama 24 jam dan 
dihaluskan dengan mesin kemudian dilakukan ekstraksi dengan menggunakan etanol $90 \%$, sehingga didapatkan perubahan berat rebung setelah menjadi ekstrak kering terbesar adalah rebung bambu apus menyusut sebesar $94 \%$ dan yang terkecil penyusutannya adalah rebung bambu betung sebesar $38.4 \%$ seperti terlihat dalam tabel berikut ini:

Tabel 1. Berat rebung sebelum dan sesudah menjadi serbuk rebung

\begin{tabular}{|c|l|c|c|c|}
\hline No & Jenis rebung & Berat basah & Berat kering & Berat ekstrak \\
\hline 1 & Rebung bambu kuning & $4750 \mathrm{gr}$ & $365.28 \mathrm{gr}$ & $339.71 \mathrm{gr}$ \\
\hline 2 & Rebung bambu wulung & $4900 \mathrm{gr}$ & $347.52 \mathrm{gr}$ & $333.62 \mathrm{gr}$ \\
\hline 3 & Rebung bambu apus & $4900 \mathrm{gr}$ & $306.25 \mathrm{gr}$ & $294 \mathrm{gr}$ \\
\hline 4 & Rebung bambu hijau & $4950 \mathrm{gr}$ & $429,2 \mathrm{gr}$ & 371,97 \\
\hline 5 & Rebung bambu betung & $5100 \mathrm{gr}$ & $3264 \mathrm{gr}$ & $3141.6 \mathrm{gr}$ \\
\hline
\end{tabular}

Tabel 2. Hasil analisis uji proksimat

\begin{tabular}{|c|l|l|l|c|c|c|}
\hline \multirow{2}{*}{ No } & \multirow{2}{*}{ Jenis rebung } & \multicolumn{5}{|c|}{ Kandungan } \\
\cline { 3 - 6 } & & Protein (\%) & Lemak (\%) & Air (\%) & Abu (gr) & Karbohidrat (\%) \\
\hline 1 & bambu kuning & 0.165 & 0.632 & 4.474 & 0.878 & 29.78 \\
\hline 2 & bambu wulung & 0.045 & 0.361 & 4.350 & 0.772 & 29.34 \\
\hline 3 & bambu apus & 0.41 & 0.091 & 4.234 & 0.764 & 10.35 \\
\hline 4 & bambu betung & 0.11 & 0.413 & 4.144 & 0.853 & 34.34 \\
\hline 5 & bambu hijau & 0.01 & 0.272 & 4.272 & 0.806 & 25.37 \\
\hline
\end{tabular}

Tabel 3. Hasil analisis kandungan HCN dan aktivitas antioksidan

\begin{tabular}{|c|l|c|c|}
\hline NO & \multicolumn{1}{|c|}{ JENIS REBUNG } & $\begin{array}{c}\text { Kandungan HCN } \\
\text { (sebelum perendaman) }\end{array}$ & $\begin{array}{c}\text { Kandungan HCN } \\
\text { (sesudah perendaman) }\end{array}$ \\
\hline 1 & Rebung bambu kuning & $7.055 \mathrm{mg}$ & $1.32 \mathrm{mg}$ \\
\hline 2 & Rebung bambu wulung & $13.13 \mathrm{mg}$ & $3.80 \mathrm{mg}$ \\
\hline 3 & Rebung bambu apus & $15.33 \mathrm{mg}$ & $3.98 \mathrm{mg}$ \\
\hline 4 & Rebung bambu betung & $9.425 \mathrm{mg}$ & $2.12 \mathrm{mg}$ \\
\hline 5 & Rebung bambu hijau & $14.01 \mathrm{mg}$ & $3.70 \mathrm{mg}$ \\
\hline
\end{tabular}

Tabel 4. Hasil analisis kandungan senyawa antioksidan

\begin{tabular}{|c|l|c|c|c|}
\hline \multirow{2}{*}{ No } & \multirow{2}{*}{ Jenis rebung } & \multicolumn{3}{|c|}{ Kandungan (\%) } \\
\cline { 3 - 5 } & & Plavonoid & Phenol & Vitamin E \\
\hline 1 & Bambu Kuning & $\mathbf{0 . 0 2 3 3 5}$ & 2.3385 & $\mathbf{0 . 2 7 3 7}$ \\
\hline 2 & Bambu Wulung & 0.02479 & $\mathbf{1 . 5 8 8 7}$ & 0.2935 \\
\hline 3 & Bambu Apus & 0.02468 & $\mathbf{4 . 4 3 5 2}$ & $\mathbf{0 . 3 2 8 4}$ \\
\hline 4 & Bambu Betung & 0.02479 & 1.6448 & 0.2956 \\
\hline 5 & Bambu Hijau & $\mathbf{0 . 0 2 7 7 8}$ & 1.9329 & 0.2864 \\
\hline
\end{tabular}


Tabel 5. Hasil analisis aktivitas antioksidan

\begin{tabular}{|c|l|c|}
\hline NO & \multicolumn{1}{|c|}{ JENIS REBUNG } & IC $_{50}(\mu \mathrm{g} / \mathrm{mL})$ \\
\hline 1 & Rebung bambu kuning & 4854.18 \\
\hline 2 & Rebung bambu wulung & 5332.06 \\
\hline 3 & Rebung bambu apus & 171.15 \\
\hline 4 & Rebung bambu betung & 15771.14 \\
\hline 5 & Rebung bambu hijau & 10269.09 \\
\hline
\end{tabular}

\section{PEMBAHASAN}

\section{Proksimat serbuk rebung}

Analisis proksimat terhadap ekstrak rebung dilakukan untuk mengetahui secara garis besar jumlah zat nutrisi yang berada didalamnya seperti yang terlihat dalam tabel 2.

Hasil analisis protein pada berbagai ekstrak rebung bambu (tabel.2), rebung bambu apus memiliki kandungan protein yang paling tinggi yaitu sebesar $0.41 \%$ dibandingkan dengan rebung bambu yang lainnya, sedangkan yang kandungan protein terendah adalah rebung wulung yaitu sebesar $0.045 \%$, kandungan lemak tertinggi adalah rebung bambu kuning yaitu sebesar $0.632 \%$ dan yang terendah adalah rebung apus yaitu sebesar $0.091 \%$. Kadar karbohidrat yang terbesar ada pada rebung betung sebesar $34.34 \%$ dan terendah adalah rebung bambu apus 10.35 $\%$. Bila dibandingkan dengan sayuran atau bahan pangan lainnya kandungan protein, lemak dan karbohidrat pada rebung termasuk rendah (TKPI Persagi, 2013). Kandungan serat kasar pada rebung termasuk tinggi bila dibandingkan dengan sayuran atau bahan pangan lainnya dan yang terbesar ada pada rebung bambu kuning yaitu sebesar 4.12 gram dan terendah pada rebung bambu betung 1.73 gr

Hasil analisis kadar air dengan pemanasan pada suhu $105^{\circ} \mathrm{C}$, rerata yang diperoleh dari rebung kering sebesar $4.29 \%$ dan yang terendah kadar airnya adalah rebung betung sebesar $4.144 \%$ dan rebung kuning adalah yang tertinggi $4.474 \%$. Serbuk rebung dapat disimpan dalam jangka waktu yang relatif lama apabila kadar airnya masih dibawah $10 \%$. Selain itu dengan mengetahui kadar air dalam rebung dapat diperkirakan jumlah rebung yang dibutuhkan jika akan mengekstrak rebung dalam keadaan basah.

Hasil analisa kadar abu pada ekstrak rebung dari beberapa bambu yang terlihat pada tabel 2, diperoleh kadar abu yang terbesar adalah rebung bambu kuning sebesar 0.878 gr dan terkecil adalah rebung bambu apus sebesar 0.764 gr. Tingginya kandungan mineral dalam bahan pangan 
ditentukan dengan besarnya kadar abu dalam suatu bahan pangan yang merupakan residu an-organik yang tersisa setelah bahan-bahan organik terbakar habis (Winarno, 1993).

\section{Kandungan asam sianida pada rebung}

Rebung merupakan salah satu bahan makanan yang sering dijadikan menjadi aneka olahan yang sering dikonsumsi oleh manusia untuk sayur, lumpia , maupun obat. Rebung yang mengandung sianida, getah pada rebung mengandung zat glucosida yang mengandung racun $\mathrm{HCN}$ (Cynogenetic glucoside). Sianida dalam tubuh dapat diubah menjadi tiosianat dan berikatan dengan vitamin B12, bila jumlahnya sedikit tetapi jika jumlahnya tinggi akan mengikat bagian aktif enzim sitokrom oksidase yang berdampak pada berhentinya metabolisme sel secara aerobik.

Dari hasil penelitian telah diperoleh bahwa beberapa ekstrak rebung bambu (tabel.3) perubahan warna dari kuning menjadi warna orange pada kertas saring menandakan adanya HCN dan jumlah yang paling banyak mengandung HCN adalah rebung bambu apus sebesar $3.98 \mathrm{mg} /$ $100 \mathrm{gr}$ atau $3.98 \mathrm{mg} / \mathrm{kg}$ rebung dan yang terendah adalah rebung kuning yaitu sebesar $1.32 \mathrm{mg} / 100 \mathrm{gr}$ atau $132 \mathrm{mg} / \mathrm{kg}$ rebung dan menurut standar FAO termasuk aman untuk dikonsumsi karena dibawah <
$50 \mathrm{mg} \mathrm{HCN} / \mathrm{kg}$. Untuk mengurangi kadar HCN dalam rebung dapat dilakukan dengan cara perendaman selama 2 x 12 jam, karena glucosida dalam HCN tahan terhadap pemanasan hingga $140^{\circ} \mathrm{C}$ (Nengah , 2009). Musim kemarau yang panjang menyebabkan kadar HCN rebung akan semakin tinggi dan rebung yang usianya semakin tua maka kadar HCN nya juga semakin bertambah tinggi.

\section{Kandungan senyawa antioksidan}

Antioksidan mampu meredam radikal bebas dengan menyumbangkan satu atau lebih elektron kepada radikal bebas dan kemampuannya sebagai inhibitor (penghambat) reaksi oksidasi. (Suhartono, 2002). Antioksidan mampu menghambat proses terjadinya aterosklerosis dengan mensekresi VCAM-1 pada endotel sehingga proses oksidasi LDL dalam lesi aterosklerotik dapat ditekan. Antioksidan juga mampu menghambat toksisitas LDL yang teroksidasi, mengurangi degradasi oksidatif akibat nitrit oksida (Morel DW.d Corleto PE, Chisolm Gm, 1984). Beberapa senyawa antioksidan yang terdapat dalam rebung diantaranya adalah Vitamin E (alfa tokoferol), Plavonoid dan Phenol.

Vitamin E merupakan antioksidan mampu memproteksi sel-sel membran serta LDL (Low Density Lipoprotein) kolesterol dari radikal bebas, membantu memperlambat proses penuaan pada arteri dan melindungi 
tubuh dari kerusakan sel-sel yang akan menyebabkan penyakit kanker, penyakit hati dan aterosklerosis. Vitamin E berperan dalam menurunkan terjadinya oksidasi LDL, mencegah terjadinya injury pada endotel, menurunkan reaksi inflamasi cytokin, menurunkan agregasi platelet (Maydani.M. 2001). Kandungan Vitamin E tertinggi dalam ekstrak rebung terdapat pada rebung bambu Apus yaitu sebesar $0.3284 \%$ seperti terlihat dalam tabel 4.

Salah satu kelompok senyawa fenolik yang memiliki sifat antioksidatif dan kardioprotektif adalah flavonoid yang mampu mencegah kerusakan sel dan komponennya dari radikal bebas dengan mendonasikan atom hidrogennya serta kemampuan mengkelat logam (Manthey dan Najla Guthrie ,2002). Hasil analisis seperti pada tabel 4 di temukan bahwa kandungan plavonoid total tertinggi terdapat pada ekstrak rebung bambu hijau yaitu sebesar $0.02778 \%$.

Polifenol merupakan suatu kelompok antioksidan yang mempunyai kemampuan menghambat reaksi oksidasi dan menangkap radikal bebas, serta antiradical yang secara alami banyak terdapat dalam sayur-sayuran, buah-buahan, dan minuman. Senyawa fenol mampu mencegah oksidasi LDL 20 kali lebih kuat dibandingkan dengan vitamin E. Kandungan Phenol dalam ekstrak rebung bambu paling banyak terdapat pada ekstrak rebung bambu apus sebesar 4.4352 $\%$.

\section{Aktivitas antioksidan pada rebung}

Uji aktivitas antioksidan menggunakan metode DPPH menunjukan adanya aktivitas antioksidan pada ekstrak rebung. Besarnya aktivitas antioksidan ditandai dengan nilai IC $_{50}$, yaitu konsentrasi sampel yang dibutuhkan untuk menghambat $50 \%$ aktivitas radikal bebas dibanding kontrol (regresi linier). Nilai $\mathrm{IC}_{50}$ yang semakain kecil maka semakin kuat kemampuannya sebagai antioksidan. Rebung bambu apus memperlihatkan aktivitas antioksidan tertinggi dibandingkan dengan rebung lainnya dengan nilai IC $_{50}$ yang dimilikinya sebesar $171.15 \mu \mathrm{g} / \mathrm{mL}$.

Aktivitas antioksidan rebung bambu apus lebih kuat dibandingkan dengan rebung bambu lainnya lain karena memiliki nilai IC 50 dibawah 200 mg/L (Hanani et. al 2005). Apabila dibandingkan dengan aktivitas antioksidan BHT yang memiliki nilai IC50 sebesar 11, $59 \mathrm{mg} / \mathrm{L}$, aktivitas antioksidan rebung masih lebih rendah tetapi masih lebih tinggi daripada temulawak.

\section{REFERENSI}

Akao Y, Seki N, Nakagawa Y, Yi H, Matusumoto K, Ito Y, Ito K, Funaoka M, Maruyama W, Naoi M, Nozawa Y, 2004. A highly bioactive lignophenol derivative from bamboo lignin exhibit a potent activity to suppress apoptosis induced by oxidative stress in human neuroblastoma SH-SY5Y cells. Bio and Med Chem 12:4791-801. 
Alimuddin, 2007, Eliminasi asam sianida dengan perbusan pada rebung bambu, jurnal kimia mulawarman vol.4, nomor 2 .

Araujo V, Arnal C, Boronat M, et al. 1998. Oxidantanti oxidant imbalance in blood of children with juvenile rheumatoid arthritis. Bio Factor. 8:155-59.

Bagiada, A. 1995. Radikal Bebas dan Antioksidan. Jurnal Kedokteran Universitas Udayana 26(89). Penerbit Unud :9-136.

Barus.Pina.2009. Pemanfaatan bahan pengawet dan antioksidan alami pada industri bahan makanan, MIPA USU, Medan. :1-25

Brown.M.S,. and Goldstein,J.L.1983. Lipoprotein metabolism in the macrophage : Implications for cholesterol deposition in atherosclerosis. Annu. Rev. Biochem.52, :223 - 261.

Bruno RS, Leonard SW, Atkinson J, et al. 2006. Faster plasma vitamin E disappearance in smokers is normalized by vitamin $\mathrm{C}$ supplementation. Free Radic Biol Med. ;40(4):689-697.

Choudhury.D, Jatindra K. Sahu.J.K, and Sharma.G.D.2010. Biochemistry of Bitterness in Bamboo Shoots. Assam University Journal of Science \& Technology : Physical Sciences and Technology. Vol. 6. Number II: 105-111

Daugherty Alan.1994. lipoprotein receptors in artenal tissue; relation to the pathology of atherosclerosis. Coronary Artew Discase. $.5: 211-215$

Fardiaz, S. 1989. Penuntun Praktek Mikrobiologi Pangan. Institut Pertanian Bogor, Bogor

Food and Nutrition Board, Institute of Medicine.2000. Vitamin E. Dietary reference intakes for vitamin C, vitamin E, selenium, and carotenoids. Washington D.C.: National Academy Press :186-283.

Goldstein, J.L., and brown, M.S.1979. Low density lipoprotein pathways and its relation to atherosclerosis. Annu. Rev.Biochem.46:897 930.

Groff JL1995. Advanced Nutrition and Human Metabolism. 2nd ed. St Paul: West Publishing

Hanani E, Abdul M, Ryany S. 2005 Identifikasi Senyawa Antioksidan dalamSpons Callyspongia sp dari Kepulauan Seribu. Majalah Ilmu Kefarmasian2:127-133.
Harini M.S, Ervizal A.M.Z, Ellyn K.D.2008. Kamus Penyakit dan Tumbuhan Tanaman Obat Indonesia. Jakarta. Yayasan Obor.

Herbert V.1996. Prooxidant effects of antioxidant vitamins: Introduction. J Nutr ;126(Suppl.4):1197S-2008S

Hernawati. 2005. Peran berbagai sumber serat dalam dinamika kolesterol pada individu hiperkolesterolemia dan normokolesterolemia, Bandung (tidak dipublikasikan).

Hessler,J.R, Morel,D.W., lewis,L.J, and Chilsolm, G.M.1983. Lipoprotein oxidation and lipoprotein-induced cytotoxity. Arteriosclerosis $3: 215$ - 222.

Horvath PJ. 1992. Vitamins as therapeutic agent. In: Smith CM, Reynard AM. Ed, Texbook of pharmacology. WB Saunders Company. Philadelphia; p1067-78.

Hu CH, Zhang Y, David DK.2000. Evaluation of antioxidant and prooxidant activities of bambooPhyllostachys nigra var. henonis leaf extract in vitro. J Agric Food Chem 48(8) 3170-6.

Jahari AB, Sumarno I. 2002. Epidemiologi Serat di Indonesia, Simposium Seminar hasil Monica III, Pusat Jantung Nasional Harapan Kita, Jakarta

Jiao.J, Zhang.Y, Lou. D, Wu. X, Zhang.Y. 2008. Antihyperlipidemic and antihypertensive effect of a triterpenoid-rich extract from bamboo shavings and vasodilator effect of friedelin on phenylephrine-induced vasoconstriction in thoracic aortas of rats. Phytotherapy research : PTR (impact factor: 1.75). 01/; 21(12):1135-41

Kamaluddin, MT.1992. Farmakologi Obat Anti Hiperlipidemia. Available in: http://www.cermindunia kedokteran.com.

Kottke.B.A. Subbiah MTR. 1978. Pathogenesis of artherosclerosis. Mayo Clin Proc. .53:3548.

Kritchevsky, S. B.1999. $\beta$-Carotene, Carotenoids and the Prevention of Coronary Heart Disease. Journal Of Nutrition 129: 5-8,

Kustiyah I, Prasetyo A. 2003. Pengaruh berbagai variasi dosis ekstrak morinda citrifolia terhadap kadar lipid serum dan perkembangan lesi aterosklerosis pada aorta 
abdominalis tikus Wistar. Media Medika Indonesia. ; 38 (4)

Lavoiser Al.1998. Chemical and physiological properties of vitamins. In: Combs GF,Ed. The vitamins. Fundamental aspects in nutrition and health. 2nd ed. London; Academic Press; p. 191-263.

Libby.P. and Aikawa.M.2002. Vitamin C, Collagen, and Cracks in the Plaque. Circulation 105:1396-1398

Li.D, Metha,J.L. 2005. Oxidized IDL, a critical factor in atherogenesis. Cardiovascular Research 68. $353-354$.

Lu.B, Wu.X, Shi.J, Dong.Y, Zhang.Y.2006. Toxicology and safety of antioxidant of bamboo leaves. Part 2: developmental toxicity test in rats with antioxidant of bamboo leaves Food and chemical toxicology : an international journal published for the British Industrial Biological Research Association (impact factor: 2.11). 11/ 44(10):1739-43.

Majid,A. 2008. Jantung koroner: patofisiologi, pencegahan dan pengobatan terkini ( Pidato pengukuhan guru besar ), Medan. Universitas Sumater Utara.

Maydani.M. 2001. Vitamin E and Atherosclerosis: Beyond Prevention of LDL Oxidation. J. Nutr. 131; 366S-368S,

Mayes PA, 1997. Sintesis, Pengangkutan dan Ekskresi Kolesterol, In: Murray RK, Granner. DK, Mayes PA, dan Rodwel VW, (Eds), Biokomia Harper, Ed. 24, Jakarta: EGC; .p. 277-89.

McCullough, F., et al.1999. The effect of vitamin A on epithelial integrity. Nutr Soc. volume 58: pages 289-293.

Montgomery R, Dryer RL, Conway TW, Spector AA.1983. Biokimia suatu Pendekatan Berorientasi Kasus. Jilid 2, Edisi 4, .Gajah Mada University.

Morel DW.d Corleto PE, Chisolm Gm. 1984. Endothelial and smooth muscle cells alter low density lipoprotein in vitro by free radical oxidation. Arteriosclerosis. .4: 357-364

Muhtadi,D., Palupi,N.S. dan Astawan,M. 1992. Metode Kimia Biokimia dan Biologi dalam Evaluasi Nilai Gizi Pangan Olahan. Bogor. PAU Pangan dan Gizi IPB
Nengah K.P.I, 2009. Efektifitas berbagai cara pemasakan terhadap penurunan kandungan asam sianida berbagai jenis rebung bambu, Agrotekno vol 15, nomor 2, agustus 2009-40

Nirmala Chongtham, Madho Singh Bisht, and Sheena Haorongbam 2011, Nutritional Properties of Bamboo Shoots: Potential and Prospects for Utilization as a Health Food. Comprehensive Reviews in Food Science and Food Safety. Vol.10, $153-169$

Nursalam,2003. Konsep Penerapan metodologi Penelitian Ilmu Keperawatan, Pedoman Skripsi, Tesis, Instrumen Penelitian Keperawatan. Jakarta : Salemba Medika.

Olwin Nainggolan, Cornelis Adimunca 2005. Diet Sehat dengan Serat, Cermin Dunia Kedokteran No. 147, : 43 - 46

Parekh.J and Chanda.S. 2007. In vitro antibacterial activity of the crude methanol extract of woodfordia fruticosa kurz flower (lythraceae).Brazillian.J. Microbial. ; 38 : 204 207.

Park.E.J, John.D.Y. 2009. Effect of bambooshoot consumption on lipid profiles and bowel function in healthy young women. Nut.J. Jul Aug : 25 (7-8): 723 - 8.

Prangdimurti.E, Palupi.N.S, dan Zakaria.F.R 2007.Metode evaluasi nilai biologis karbohidrat dan lemak. Bogor Fateta IPB: 1 17.

Price.Sylvia.A, Wilson. Lorraine.M. 1995 .Patofisiologi konsep klinis proses-proses penyakit, edisi 4. Jakarta: Penerbit EGC; .p.529 - 555 .

Proctor PH, Reynolds ES.1984. Free radicals and disease in man. Physiol Chem Phys Med.16; :175-95.

Putra I.N.K, 2009, Efektifitas berbagai cara pemasakan terhadap penurunan kandungan asam sianida berbagai jenis rebung bambu. Agrotekno vol 15, nomor 2, Agustus 2009-40.

Raharjo.Sri.2005. Oksidasi lipoprotein densitas rendah dan atrosklerosis. Agretech Vol.17.No.1 .: $26-32$.

Rai, Surabhi.2007. Edible bamboo shoot-a review, Bulletin of arunachal forest research 23 (1\&2): 39-44, 
Rana, M., Khanam, J.A. dan Asad-Ud-Daula, M.2008. , Antineoplastic screening of some medicinal plants against Ehrlich ascites carcinoma in mice, J. Med. Sci., 4 (2) :142-145.

Rosenfeld,M.E, Tsukada.T, Gown,A.M, and Ross,R. 1987. Fatty streak initiation in watanabe heritable hyperlipidemic and comparably hypercholesterolemic fat-fed rabbits, Arteriosclerosis I: 9 -23.

Sampurno. 2003.Pengaruh pemberian ekstrak allium sativa terhadap jumlah sel busa dan ketebalan dinding aorta abdominalis tikus Wistar. Tesis. Semarang.

Sargowo.D. 1997.Peran Radikal bebas dalam patogenesa Aterosklerosis, jurnal Kardiologi Indonesia / Vol. XXII No.3, Juli-September 1997: 168-182.

Semba RD. 1998 .The role of vitamin A and related retinoids in immune function. Nutr Rev. 56(1 Pt 2):S38-48.

Semba RD. 2001. Impact of vitamin A on immunity and infection in developing countries. In: Bendich A, Decklebaum RJ, eds. Preventive Nutrition: The Comprehensive Guide for Health Professionals. 2nd ed. Totowa: Humana Press Inc :329-346.

Silalahi, J. 2000. Hypocholesterolemic Factors in Foods: A Review. Indonesian Food and Nutrition Progress, 7: 26 - 35.

Soesanto, E. (2018). Compounds Antioxide of Extract Yellow and Green Bamboo Shoot. Media Keperawatan Indonesia, 1(1), 42-47. doi:https://doi.org/10.26714/mki.1.1.2018.4 $2-47$

Soesanto, E. 2010. Faktor-faktor yang berhubungan dengan praktik pengendalian kesehatan pada lanjut usia Hipertensi di Wilayah kerja Puskesmas Mranggen, Demak, Tesis, UNDIP.

Spagnoli,L.G, Bonanno. E, Sangiorgi.G, and Mauriello.. 2007. A. Role of Inflammation in Atherosclerosis J Nucl Med 48:1800-1815

Stemme S. Hansson GK. 1994. Immune mechanisms in atherosclerosis. Coronary Artery disease.5: $216-222$.
Stark, A., Madar, Z. Dietary fibre. In: Goldberg, I (ed). 1994. Functional Foods: Designer Foods, Pharmafoods, and Nutraceuticals. Chapman \&Hall. New York : p. 183-201.

Suharto, I.2000. Pencegahan dan Penyembuhan Penyakit Jantung Koroner. Jakarta : Gramedia Pustaka Utama.

Suhartono, E., Fujiati, Aflanie, I. (2002). Oxygen toxicity by radiation and effect of glutamic piruvat transamine (GPT) activity rat plasma after vitamine $\mathrm{C}$ treatmen, Diajukan pada Internatinal seminar on Environmental Chemistry and Toxicology, Yogyakarta.

Sukandar.E. 2006. Stres oksidatif sebagai faktor resiko penyakit kardiovaskuler pada penyakit ginjal kronis tahap 1 sampai 4. Majalah Farmacia Edisi Agustus : 64

Traber MG. 1999. Utilization of vitamin E. Biofactors ;10(2-3):115-120.

Traber MG. 2001. Does vitamin E decrease heart attack risk? summary and implications with respect to dietary recommendations. J Nutr ;131(2):395S-397S.

Traber MG. 2006. Vitamin E. In: Shils ME, Shike M, Ross AC, Caballero B, Cousins RJ, eds. Modern Nutrition in Health and Disease. Philadelphia: Lippincott Williams \& Wilkiins; 396-411.

Trilling JS, Jaber R,1996. Selections from current literature: the role of free radicals and antioxidants in disease. Fam Pract;13(3):3226.

Winarno, 1992. Rebung (Teknologi Produksi dan Pengolahan), Jakarta: Pusaka Sinar Harapan.

Winarno, F. G. 1993. Pangan, Gizi, Teknologi dan Konsumen. PT Gramedia. Jakarta.

Wiryowidagdo, S \& Sitanggang, M.2002. Tanaman Obat Untuk Penyakit Jantung, Darah Tinggi dan Kolesterol. Jakarta : Agromedia Pustaka.

Zhang.Y, Tie. X, Bao.B, Wu.X, Zhang.Y.2007. .Metabolism of flavone C-glucosides and pcoumaric acid from antioxidant of bamboo leaves $(\mathrm{AOB})$ in rats.The British journal of nutrition (impact factor: 3.45). 04/2007; 97(3):484-94. 